UNIVERSIDAD DEL CEMA

Buenos Aires

Argentina

Serie

DOCUMENTOS DE TRABAJO

\author{
Área: Economía \\ INNOVATORS AND INNOVATIONS IN \\ HIGH QUALITY WINES OF ARGENTINA
}

Julio Elías and Gustavo Ferro

Agosto 2018

Nro. 651

https://ucema.edu.ar/publicaciones/doc_trabajo.php UCEMA: Av. Córdoba 374, C1054AAP Buenos Aires, Argentina

ISSN 1668-4575 (impreso), ISSN 1668-4583 (en línea)

Editor: Jorge M. Streb; asistente editorial: Valeria Dowding <jae@cema.edu.ar> 



\title{
Innovators and Innovations in High Quality Wines of Argentina ${ }^{1}$ \\ Julio Elías ${ }^{2}$ and Gustavo Ferro ${ }^{3}$
}

\begin{abstract}
:
How does the process of applying knowledge to the economy work? How do people innovate? What is inside the innovation black box? Can the process be stylized? We apply an economic approach to creativity which provides a general analytical framework to innovation to answer these questions by distinguishing two types of innovations: conceptual and experimental. The development of quality wines which in Argentina began in the 1990s was a process that involves both types of innovations. We analyze two cases of successful winemakers and we characterize their process of innovations to derive lessons with potential managerial and public policy implications.
\end{abstract}

\section{Resumen:}

¿Cómo funciona el proceso de aplicar conocimiento a la economía? ¿Cómo innova la gente? ¿Qué hay dentro de la caja negra de la innovación? ¿Cómo puede estilizarse el proceso? Aplicamos un enfoque económico de la creatividad que provee un marco analítico generalpara responder estas preguntas, distinguiendo dos tipos de innovaciones: conceptuales y experimentales. El desarrollo de los vinos de alta calidad en Argentina comenzó en los 1990s y fue un proceso que tuvo ambos tipos de innovaciones. Analizamos dos casos de bodegueros exitosos y caracterizamos sus procesos de innovación para derivar lecciones con potenciales implicaciones gerenciales y de política pública.

Key words: Innovation, Wine industry, Argentina

JEL Codes: O31, Q13

\footnotetext{
${ }^{1}$ A previous and abridged versión was presented at the 12th Annual Conference of the American Association of Wine Economists, June 10-14, 2018, Ithaca NY, held at Cornell University. The points of view in this paper do not necessarily rereflect the views of Universidad del CEMA.

${ }^{2}$ Universidad del CEMA (UCEMA). Córdoba 374, Buenos Aires, Argentina. Email: je49@ucema.edu.ar

${ }^{3}$ Universidad del CEMA (UCEMA) \& CONICET. Córdoba 374, Buenos Aires, Argentina. Email: gaf97@ucema.edu.ar
} 


\section{Introduction}

What is the knowledge economy? Which is its relationship with business? In discussing the Industrial Revolution of the 1840's, Becker (2005) called the "Knowledge Revolution" the process of systematic application of science to the economy. This led to a huge burst in productivity, driven by advances in scientific and other knowledge relevant to economies.

The increase in scientific knowledge led to accumulation of education and other human capital, and the interactions between different forms of knowledge led to the "modern economy" that is heavily dependent on the implementation of existing knowledge, its transference to future generations, and the development of additional knowledge. How does this process of applying knowledge to the economy work? How do people innovate? What is inside the innovation black box? Can the process be stylized?

The economic approach to creativity provides a general analytical framework to answer these questions by distinguishing between two types of innovations: conceptual and experimental (Galenson, 2007). Using case studies and empirical analysis, systematic and very different patterns of innovation can be identified according to the type of innovator. The motivations and methods of the innovator are closely connected to both the nature of their innovation and their life cycles of creativity.

Conceptual innovations tend to be dramatic; in most cases they consist of something completely different, that break the conventional rules of a discipline or activity. Generally, conceptual innovators have precise goals in advance, what allows them to plan their work and execute it decisively. Their most radical new ideas, and consequently their greatest innovations, tend to occur early in their careers.

Experimental innovations develop gradually, by a process of trial and error. Experimental innovators proceed tentatively, building their skills gradually and tend to make their greatest contributions late in their careers.

In contrast with conceptual innovations, where their breakthrough ideas are easy to communicate among people in the same field, experimental innovations are difficult to spread because they are hard to communicate (Polanyi, 1998, call them tacit knowledge). Experimental innovations should be experienced to understand and incorporate.

The development of quality wines in Argentina that began in the early 1980s was a dynamic process that combined both conceptual and experimental innovations and provides a great opportunity to learn about the process of innovation. 
To examine the innovation black box and get the details, we analyze two cases of three innovators and successful winemakers who drove the development of quality wines in Argentina: Catena, Etchart and Rolland.

Nicolás Catena is one of the most important innovators in the international wine industry. Armed with his experimental approach, when he was in fifties, Catena developed an entire new industry of quality wines in Argentina and resurrected the Malbec wine during the 1990s. The main innovations (or revolutions) introduced by Catena are three ${ }^{4}$ : the use of the Californian-French vinification style to produce quality wines in Argentina; the discovery and development of high-altitude Malbec wine; and the discovery that the soils from Mendoza are not homogenous within very short distances, resulting in vineyard lots with unique characteristics. This last discovery is still in development and prompted the Catena family to drill down even deeper into the theory of terroir.

Arnaldo Etchart was the winegrower who brought the French expert Michel Rolland to Argentina in 1988 to break the local practices of wine producing. He has the idea that it was possible to produce quality wine for the international market in Argentina by combining the appropriate knowledge and human capital with the local resources. Michel Rolland is the young conceptual innovator who in his early thirties was able to revolutinaze the wine industry by introducing new practices for grape growing.

The collaboration of these two conceptuals innovators had immediate results. In 1990, Arnaldo Etchart and Michel Rolland bring to market one of the first premium wines of Argentina: Arnaldo B. Etchart Harvest 1989. In 1995, the first wines of San Pedro de Yacochuya go out to the domestic market. In 2001, the San Pedro de Yacochuya winery exports its first premium wine (Yacochuya M. Rolland 1999 harvest), produced at 2000 meters above sea level and being one of the highest vineyards in the world. The winery is equipped with the newest and most modern technology. Those wineries are located out of the core wine region in Argentina. Also, Etchart is responsible of the successful introduction of Torrontés white grape in the international markets.

In this paper, we characterize both processes of innovations with the aim of deriving lessons with managerial and public policy implications.

\footnotetext{
${ }^{4}$ Previously, in the early 1970 s Catena was also a pioneer in marketing its products in the local market. At the time, most of the locally consumed wines were bulk wine. He sold it under different commercial brands and started to publicize on television. Sales soared and the product earned legitimation as a family beverage, to enjoy with cherished ones (Mount, 2012).
} 
After the Introduction, Section 2 presents the approach to creativity and innovation we follow and its application to Argentine wine industry, Section 3 provides a brief background on the evolution of Argentine wines in recent decades, Section 4 present a case of experimental innovation (the work of Nicolás Catena), Section 5 present a case of conceptual innovation (the work of Etchart and Rolland) and Section 6 concludes.

\section{Creativity and Innovation}

Based on the study of the careers of more than two hundred artists, Galenson (2007) establishes that there are two types of innovators in art: conceptual innovators, who plan in detail before performing a work, and experimental innovators, who make the most important decisions about their work while performing their art. The same pattern can be identified in literature, music, business and academic careers. Table 1 summarizes goals, methods and the nature of the outcomes of each type of innovator.

Conceptual innovators have precise objectives in advance that allow them to plan their work, and execute it decisively. Their radical new ideas, and consequently their greatest innovations, appear early in their careers.

In contrast, experimental innovators don't have a defined objective, and as a consequence, they work through a search process. Experimental innovators proceed tentatively, through a process trial and error, building their skills gradually as their work progresses.

For an experimental innovator, there is no such thing as a finished project. Their skills, and therefore their work, improve over time, one job carried over to another. This is why their careers are dominated by work on a topic or problem, instead of the pursuit of a single goal. 
Table 1: Galenson's typology of innovations when describing artistic creation

\begin{tabular}{|l|l|l|l|}
\hline Innovators & Goals & Methods & Outcomes \\
\hline Experimental & $\begin{array}{l}\text { Imprecise in advance and } \\
\text { evolutionary. } \\
\text { The goal is a topic or } \\
\text { problem. }\end{array}$ & $\begin{array}{l}\text { Tentative and } \\
\text { incremental. } \\
\text { Trial and error. }\end{array}$ & $\begin{array}{l}\text { Slow building of skills } \\
\text { yields to a body of work }\end{array}$ \\
\hline Conceptual & $\begin{array}{l}\text { Specific and sudden } \\
\text { (discontinuous). } \\
\text { The goal is precise. }\end{array}$ & $\begin{array}{l}\text { Goals stated in advance. } \\
\text { Detailed preparatory } \\
\text { plans. }\end{array}$ & $\begin{array}{l}\text { A final work developed } \\
\text { systematically }\end{array}$ \\
\hline
\end{tabular}

Source: Own elaboration, based on Galenson (2007).

In what follows, we show that these same patterns apply to innovators in the quality wine industry of Argentina. The wine industry has experimented drastic changes in Argentina, from a local-oriented, commodity-type industry, to an export-oriented, differentiated product industry. Making to the international stage of high quality wines required changes in the way the industry works, machinery, techniques, marketing and the whole business approach, but also demanded the break of old ways of thought and a different type of skilled and open minded human capital.

The main objective of our two case studies is to to gain a general understanding of the quality wine industry evolution in Argentina, and especially the innovation process which led to its current stage. The case studies were elaborated by contacting industry referents, conducting interviews, and consulting academic studies and industry reports.

Table 2 summarizes the two case studies and their main features. It identifies and classiffy their main innovations and connect them with the characteristics of their process of innovation.

Table 2: Selected cases of study and their characterization

\begin{tabular}{|c|c|c|}
\hline Case of Study & Type of innovator & Focus \\
\hline Catena & Experimental & $\begin{array}{l}\text { 1. 19980s-1990s intent to replicate California's revolution in } \\
\text { Argentina. } \\
\text { 2. 1990s-2000s the development of a local grape insignia (Malbec). } \\
\text { 3. 2010s-nowadays, experimentation in different heights and } \\
\text { terroirs. }\end{array}$ \\
\hline Etchart \& Rolland & Conceptual & $\begin{array}{l}\text { 1. 1990s concept: world class wines can be produced outside Old } \\
\text { World traditional producers, by combining high quality practices } \\
\text { and technology with local resources (land and varieties). In } \\
\text { doing so, hiring of international experts to implant new } \\
\text { practices and know how. } \\
\text { 2000s-nowadays, diffusion of Torrontés and high quality } \\
\text { Malbecs in a peripheric productive zone of Argentina (Salta). }\end{array}$ \\
\hline
\end{tabular}




\section{Argentine Wines in the Context of New World Wines}

The emergence in the early 1970s of new high-quality wines in California showed to the world that it was possible to produce high-quality wines outside France. Wineries throughout the world started to compete with the "Old World" wines by producing "New World" wines. The monopoly of terroir plus origin denomination ceded place to varietal wines, cheaper than the former and increasingly of better quality. On the demand side, consumption increased in geographical reach and expanded in social groups of consumers. Table 3 compares the main features of both groups of producers.

In South America, the pioneers in the innovation and internacionalization of their wines were the Chileans, since in the early 1970s the Spanish winery Miguel Torres invested in land and imported technology locally. The whole industry modernized and started to be an international player (Bustos et al., 2007).

A decade later, Argentina started its incorporation to international markets as a New World producer. Historically, its production was important in volume but not in international quality standards and its initial participation in the international markets were negligible (De Francesco et al, 2013).

Table 3: Wine market patterns

\begin{tabular}{|l|l|l|}
\hline Market segment & Quality & Main Features \\
\hline Old World & Relatively high & Tradition \\
& & History \\
& & Prestige (Name) \\
& & Terroir \\
& & Origin denomination \\
& & Leontieff-type technology \\
\hline New World & Increasingly high & Innovation \\
& & Differentiation \\
& & Varietals and flexible technology of production \\
& & Affordability \\
& & Informational content of labels \\
\hline
\end{tabular}

Source: Own elaboration.

Table 4 shows the evolution of New World producers in the international market. As recently as in 1990, the New World 6 (NW6) $)^{5}$ exports in volume were slightly greater than the 7 percent of Old World $6(\mathrm{OW} 6)^{6}$ ones, in value they were only 4.5 percent, and the average price of exports of NW6 was 62 percent of the OW6.

\footnotetext{
${ }^{5}$ Here defined as the sum of Argentina, Australia, Chile, New Zealand, South Africa and the United States.

${ }^{6}$ Here defined as the sum of France, Germany, Greece, Italy, Portugal and Spain.
} 
Table 4: Wine export market

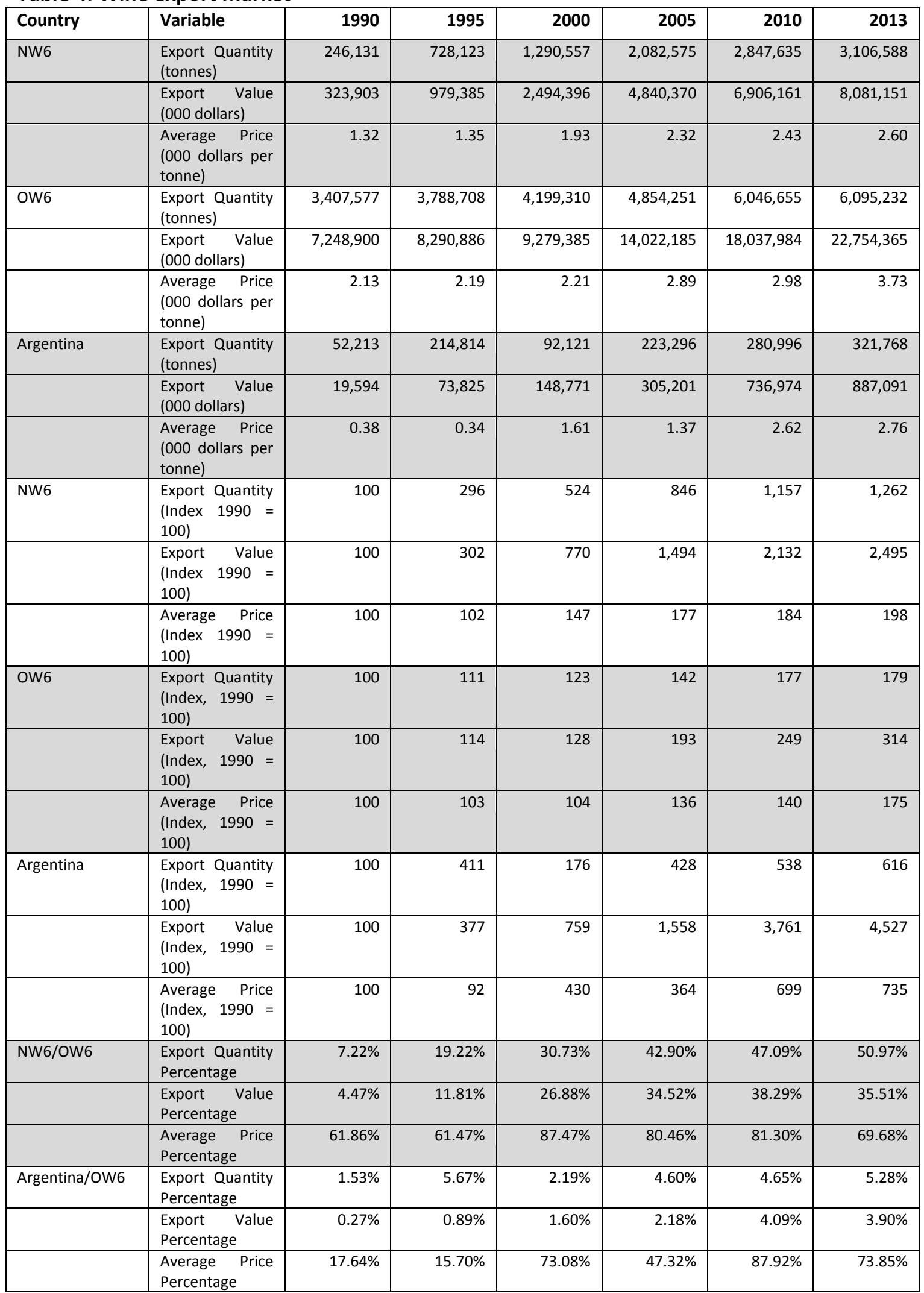

Source: FAOSTAT (as for February 20th, 2018). NW6 = New World 6 (Argentina, Australia, Chile, New Zealand, South Africa, United States). OW6 = Old World 6 (France, Germany, Greece, Italy, Portugal, Spain) 
Between 1990 and 2013, the NW6 grew 1,162 percent in export volume, 2,395 percent in export value and doubled the export price per unit, while the OW6 improves 79 percent in export volume, 214 percent in export value, and 75 percent in average unit price.

The NW6 export volumes in terms of OW6 ones went from 7 to 51 percent. In export values, NW6 represents now 36 percent of the OW6 ones. Thus, the gap in prices was filled in a great deal (and the last disposable information shows a worst panorama than five years earlier).

Argentina grew at half the velocity of NW6 in volumes but at twice the values. Its average price was sensible lower than the average of NW6 in 1990, exceeding now the average.

One approximation to the quality of wine exports can be made by relating the price received for each country as a proportion of the best rated, that is the French wines. Argentina was at the end of the list of twelve countries in 1990, and has improved considerably in relation to the benchmark and with respect to other New World competitors. Along with New Zealand, Australia and Portugal, Argentina have experimented the highest volatility of relative prices in exports markets (See Table 5).

Table 5: Vine export price as a proportion of French wine export prices in selected periods

\begin{tabular}{|c|c|c|c|c|c|c|c|c|}
\hline Country & 1990 & 1995 & 2000 & 2005 & 2010 & 2013 & $\begin{array}{l}\text { Average } \\
1990- \\
2013\end{array}$ & $\begin{array}{l}\text { Std. Dev. } \\
1990- \\
2013\end{array}$ \\
\hline Argentina & 0.11 & 0.09 & 0.47 & 0.27 & 0.44 & 0.40 & 0.29 & 0.11 \\
\hline Australia & 0.73 & 0.63 & 0.85 & 0.59 & 0.41 & 0.37 & 0.64 & 0.20 \\
\hline Chile & 0.35 & 0.35 & 0.42 & 0.41 & 0.36 & 0.32 & 0.38 & 0.04 \\
\hline $\begin{array}{l}\text { New } \\
\text { Zealand }\end{array}$ & 0.78 & 0.84 & 0.69 & 1.13 & 0.54 & 0.86 & 0.97 & 0.23 \\
\hline $\begin{array}{l}\text { South } \\
\text { Africa }\end{array}$ & 0.41 & 0.36 & 0.42 & 0.33 & 0.33 & 0.21 & 0.38 & 0.09 \\
\hline $\begin{array}{l}\text { United } \\
\text { States }\end{array}$ & 0.39 & 0.42 & 0.56 & 0.35 & 0.46 & 0.55 & 0.45 & 0.09 \\
\hline $\begin{array}{l}\text { New } \\
\text { World } 6\end{array}$ & 0.38 & 0.34 & 0.57 & 0.45 & 0.41 & 0.38 & 0.45 & 0.08 \\
\hline France & 1.00 & 1.00 & 1.00 & 1.00 & 1.00 & 1.00 & 1.00 & 0.00 \\
\hline Germany & 0.51 & 0.47 & 0.43 & 0.46 & 0.50 & 0.49 & 0.48 & 0.04 \\
\hline Greece & 0.20 & 0.34 & 0.40 & 0.41 & 0.38 & 0.43 & 0.38 & 0.07 \\
\hline Italy & 0.34 & 0.29 & 0.45 & 0.47 & 0.40 & 0.48 & 0.41 & 0.07 \\
\hline Portugal & 0.78 & 0.73 & 0.73 & 0.51 & 0.54 & 0.46 & 0.59 & 0.14 \\
\hline Spain & 0.38 & 0.38 & 0.43 & 0.27 & 0.23 & 0.27 & 0.32 & 0.07 \\
\hline $\begin{array}{l}\text { Old } \\
\text { World } 6\end{array}$ & 0.62 & 0.55 & 0.65 & 0.56 & 0.50 & 0.55 & 0.57 & 0.06 \\
\hline
\end{tabular}

Source: FAOSTAT (as for February 20th, 2018). 


\section{Experimental Innovation: Nicolás Catena and the Resurrection of Malbec}

Nicolás Catena Zapata is heir of one of the oldest and largest wineries in Argentina. Son of Domingo (in charge of the family business since 1936) and grandson of Nicola, an Italian immigrant (who founded the family winery in 1902), is currently the second wine exporter in Argentina and the largest local exporter to the OECD. Catena Wineries are situated in Mendoza, the main wine region of Argentina, located in the center-west of the country, by the highest part of the Andes Mountains which are the natural boundary with Chile.

Nicolás Catena was born in 1940. He holds a Master in economics from Columbia University, New York, where he was living when his mother died in the early 1960s, and he left an academic carrier to work in family business. At the time his father was buying wines in bulk and selling three blends of his own to bottling factories around the country. His first decisions were to bottle bulk wine under different brands and to publicize on television with great success in sales in the early 1970s but that innovation had in mind the lower quality wines in vogue at the time. In the early 1980s he sold all his facilities that were making non-premium wines (Rose, 2009).

Nicolas Catena first innovation in high quality wines started to develop at the beginning of the 1980s when he was a visiting professor of economics at UC Berkeley. He visited Californian wineries and tried high quality wines which rivalize with best French wines. Upon returning to Argentina, he tried to emulate the Californian concept after learning of production technology, consumption trends and marketing practices (Artopoulos et a., 2009).

He started working with two Californian iconic varieties ${ }^{7}$ : Cabernet Sauvignon and Chardonnay. But afterwards he shifted to improve Malbec, a grape with poor fame at the time. He also explored different soils and heights to plant his grapes, since the local weather is more extreme than in traditional "Old World" producers, with very hot and dry summers and harsh winters.

The main innovations introduced since the 1990s by Catena were three: 1) the use of the Californian-French style of producing quality wines in Argentina; 2) the development of high-altitude Malbec wine; and 3) the discovery that Mendoza's soil is not homogenous within very short distances, resulting in unique characteristics in vineyard lots. This last discovery is still under development and prompted the Catena family to further explore terroirs.

Making the first Argentine wine that could compete internationally took Catena about 8 years of elaboration. Discovering that altitude was relevant to the Malbec took him another

\footnotetext{
${ }^{7}$ In fact, they were the predominat grapes in Bordeaux and Burgundy blends.
} 
7 or 8 years, and the issue of the terroir, 10 more years. All these developments were through a process of trial and error. Bodega Catena Zapata does more than 200 different experiments per year, where each one has associated a different hypothesis.

Catena discovered that in California the ways to obtain international quality were very different from what they were doing in Argentina' (Rose, 2009). When Catena started to modernize local wine style, Argentina produced wines following an old Italian style: wine was stored in big wood barrels for three or four years and suffered a gradual oxidation, as is currently done in Porto or Jerez, or Chianti in the past. But Italians had already left that style. In the late 1970s oxidated wines were considered the opposite of a quality wine, but Argentina continued to produce with that techniques. In the 1980s, Catena started to produce reds at the Bordeaux style and whites at Burgundy style. Californian wines were produced without oxidation and their wines were of high quality. Californians in their intent to mimic French wines studied everything on French planting, vinification and maduration of wines and they ended producing a quality product (Nogueira, 2013).

Catena decided to elaborate wines trying to obtain international quality with a similar method of California, adapted to Argentina. He started that project at the beginning of the 1980s. The first wine that came out of the project was the 1990 harvest, and it was very successful. Year 1990 was the first of the new vintages using extended maceration and new French oak barriques, smaller than the historical ones. The Catena Cabernet and the Chardonnay were instant hits in the US (Personal Interview with Nicolás Catena, 2017). Nevertheless, planting Cabernet and Chardonnay in Agrelo on his return to Argentina in 1983 marked the beginning of an understanding of the relationship between temperature and climate.

He was less convinced about Malbec itself, but felt he owed it to his ageing father (decesead in 1984) to try it (Mount, 2013). In 1984, he resurrected the neglected old-vine Malbec, growing in the 80 hectares Angélica vineyard in Maipú's Lunlunta district (Rose, 2009).

Malbec is original from France, where it was a component in Bordeaux blends before phylloxera epidemic destroyed most of the vineyards for wine grapes in Europe, most notably in France, where wine production fell from 84.5 million hectolitres in 1875 to 23.4 million hectolitres in 1889. There is still some Malbec grown in Cahors, south of Bordeaux, where it is called Côt, but the grape is not important in France. But it was an important component of the assemblage of the French grand crus classified in 1855. It is a delicate grape, of late harvesting, 
very susceptible to cold and the abscense of sunlight. It adapted to the dry and sunny climate of Mendoza (Fresco, 2017).

In the mid-1800s, Malbec was introduced to Argentina. For a hundred years it was used primarily as a blending grape. Argentina's wineries made the conscious decision to start producing higher quality wine comprised entirely of the Malbec grape, and to market themselves accordingly (Hernández, 2013). The main problem was that no one really knew how to make a modern Malbec using the Californian-French technique. They worked experimenting, by trial and error. A project was started in 1992 to select the best five Malbec clones from more than 130 in the Angélica vineyard. No one in Argentina had ever perform a clonal selection to isolate and identify which clone worked in heat or cold, what kind produced more plum flavors, and so on. All this meant that Catena's viticultural staff would have to do the genetic improvements themselves. After selecting the best clones, they planted them at different altitudes and soil composition to see where each achieved its best expression (Mount, 2013).

In the process of choosing the plants, growing clones, selecting the best of them, and replicating the best clones in other vineyards to the point that they bore fruit, some five years passed. Catena was not the first to believe in Malbec. He was the first to put resources and patience to delve into its possibilities. And the experiment his company performed changed the Argentine Wine Industry (Mount, 2012). Cluster, berry size and resistance to disease were the criteria for the subsequent planting, and when he produced the first quality vintage for export, the 1994, Catena's daughter Laura (today head of the family business) convinced her father it would be well received. It was, but the 1996 vintage was Malbec's watershed, encouraging him to plant at different altitudes and blend across microclimates. Catena credits Laura, who started working at the winery from the end of the 1990s, with the discovery of the effects of sunlight intensity (Rose, 2009). With the success of Malbec, Catena decided to end his attemps to produce something similar wines to Bordeaux ones, instead offering the consumers a new flavor and aroma (Nogueira, 2013).

'In Argentina, the physical composition of soils is not relevant because humidity is controlled through irrigation. The relevant terroir factors affecting aroma and flavor are temperature, which depends on the latitude, and sunlight intensity, which depends on altitude.' He selects the best vineyard lots and then blends the best lots from different altitudes (Rose, 2009). 
The careers of experimental innovators are characterized by having one (imprecise) goal only, which reveals to them as they work, through trial and error. Because of the impresition of their goal, experimental innovators rarely feel that they have succeded in achieving it. So, they continue searching. They are perfectionists.

At a certain point in his quest for high quality, he offered his wines to a French reputed winemaker. This expert compared Catena's wines with those of Languedoc in France, a comparative hot place with lower quality on average than the best French wines. Thus, in his search for lower temperatures, Catena resolved to move all future plantings to southern and higher areas. Then, in search of lower temperatures, Catena resolved to move all future plantings south and higher to the Uco Valley at 1,440 meters over the sea level (Rose, 2009).

After elaborating that hypothesis, Catena looked for vineyards in places of lower temperature. It was an experiment, these colder places face two major risks: one was the frost (early and late), and the other one was that the grapes could not ripen. In contrast with conceptual innovators, experimental innovators take their work as research. He planted there seeking to learn. But it was an experiment: there was absolutely no guarantee of success (Personal Interview with Nicolás Catena, 2017). Catena took the risk and planted in colder places; in high places and to the south. He made trials with Chardonnay, Cabernet Sauvignon, Malbec and Pinot Noir.

Of these varietals, the Malbec behaved not just better with the cold, but produced something new, original. The Malbec was the big surprise. Catena was surprised by the response of Malbec to high altitude and cold weather. These experiments lead to the birth of the High-Altitude Malbec, Catena second's experimental innovation. Trials with clones and experiments with altitude and lower temperatures led to the realization that sunlight intensity at higher altitude could substantially improve flavor and aroma.

Low temperatures, high sunlight intensity and the poor soils near the Andes turned out to be an ideal blend, with quality controlled by strict irrigation. Clonal trials and experiments with altitude and lower temperature led to the realization that sunlight intensity at higher altitude could substantially improve flavor and aromatics (Rose, 2009).

In 1999 the Wall Street Journal published the first article on Malbec and Catena was mentioned as a pioneer. Later the Malbecs from Catena obtained several high scores (beyond 90 points) from Wine Spectator. In 2009 Dr. Catena was elected Decanter Man of the Year by Decanter Magazine. In 2012 he received the prestigious Distinguished Service Award from 
Wine Spectator Magazine, and Catena Winery received the Extraordinary Winery Award 2017, by Robert Parker (Fresco, 2013).

\section{Conceptual Innovation: Arnaldo Etchart and Michel Rolland. The Development of High Altitude wines in Salta and the popularization of Torrontés}

Important Innovations and new knowledge can be generated by innovators working in collaboration. Team work can provide access to more knowledge and new, productivity increasing ideas. A right match can generate important complementarities between team members in the production of new knowledge and innovations. At the macro level, Lucas and Moll (2014) show how these choices could affect the economy's rate of learning and real growth.

However, as highlighted by Galenson and Pope (2013) "collaborations do not succeed in many situations. A critical condition for their success is the existence of a shared body of knowledge and techniques, which Nielsen calls a shared praxis." Arnaldo Etchart and Michel Rolland shared methods, interests and a conceptual approach to innovate. The existence of a "shared praxis" beween them leaded to a long-lasting successful collaboration, that continue today with Arnaldo Etchart's sons.

At the end of the 1980s, Etchart was not satisfied with the quality of the wines that he produced at Cafayate (in the North Eastern province of Salta, location of high vineyards from 1,152 to 2,000 or more meters above the sea level) and he thought that it was possible for Argentina to break into the international market of quality wines if just they improved their method of production, but he also realized that nobody in the local market knew how to do it. When a container of his wine was returned from Europe because the color had faded from red to pink he decided to look abroad for someone with the knowledge and human capital to produce better wines.

The match between Etchart and Rolland was not random. Arnaldo Etchart, businessman and enologist graduated in San Juan, has the vision and the ability to find Rolland and brought him from Libourne, a town on Right Bank of Bordeaux, to the distant Cafayate. Rolland reached Argentina in 1988, where local wines were of low quality on average, to develop the red wines of the Etchart winery (Malbec, Cabernet Sauvignon and Tannat) and the white Torrontés District (Saieg, 2013). Once in Cafayate, Etchart would strongly support Rolland's radical new ideas and proposals of changing traditional practices, going against all his workers criteria, based in the traditions and knowledge they shared. This collaboration 
provided Rolland the opportunity of testing his conceptual new ideas of grape growing, harvesting and wine production in a wine region outside France. The new techniques include deep pruning in winter, "green-harvesting" to reduce the quantity of grapes, leaf trimming to keep the grapes exposed to sun and air, and late harvesting.

After the irruption of the Californian high-quality wines in the international stage in the 1970s, Michel Rolland introduced new techniques to improve wine quality by concentrating in the vineyard yield, going against the well established theory of the terroir as the main source of grape and wine quality. Starting in Bordeaux in the early 1980s, after an excellent vintage in 1982 , he was able to develop a well defined group of techinques that allows him to achieve a uniform good quality of wines (fruity, rich and concentrated) across very different wine regions.

The main conceptual innovation of Michele Rolland was to introduce techniques that improved the grapes and allow to obtaining good quality young wines. Shortening the horizon to produce good quality wines has a positive effect on the return of producing quality wines. His winemaking techniques allow him to produce good wines after only one to two years of aging so investors are able to recover their investment in a shorter period of time.

Etchart Winery was founded in 1850 and acquired by Arnaldo Etchart Senior in 1938. Old Etchart Winery was sold to Pernod Ricard Group in 1996, while the family continues its activity with the new winery San Pedro de Yacochuya in a joint venture with Michel Rolland, situated over 2,200 meters over the sea level in the west bank of Calchaquí Valley, near Cafayate (Saieg, 2013).

Etchart Winery is located at the foot of the Andes, over 1750 meters above sea level in one of the highest wine regions in the world. The combination of altitude, mild climate and characteristics of the Cafayate Valley result in aromatic wines of great concentration and color. Although the Cafayate Valley is located almost in Tropic of Capricorn, the higher altitudes and micro-climate of the valley are the main factors which keep temperatures within a steady range. The terroir and microclimate conditions during the day, paired with low, high desert temperatures dropping to 8 to $15^{\circ} \mathrm{C}$ by night result in fruit with balanced sugar and acidity. This wide temperature range also allows for the maturation of complex aroma and flavor compounds (Ibarguren, 2013).

According to Rolland, wine producing can be improved until certain ceiling: the upper bound is given by the relationship between soil and climate. He conceives his knowledge as the ability to reach that ceiling (Cuculiansky, 2016). Currently, Michel Rolland has hundreds of 
clients across 13 countries. At the time, there were Malbec vines planted but Argentines wanted to work other varieties, and Malbec was destinated to local bulk market. In his opinion, local wines were light, tasteless and dull, and they had to work to produce high quality grapes. As discussed in previous sections, in the 1990s the Malbec improved, they won the acceptance of international markets and local producers started to grow Malbec.

In 1990, Arnaldo Etchart and Michel Rolland brought to market one of the first premium wines of Argentina: Arnaldo B. Etchart Harvest 1989. In 1995, the first wines of San Pedro de Yacochuya go out to the domestic market. In 2001, the San Pedro de Yacochuya winery exports its first premium wine (Yacochuya M. Rolland 1999 harvest). The top wine Gran Linaje Torrontés received a score of 90 points by Robert Parker in 2010, being the best ranked white that year (Saieg, 2011).

\section{Concluding Remarks}

Both Argentine winegrowers here studied had in common the desire of producing locally, world class wines. Both, as men of their time, had in mind the historical primacy of French wines, and initially tried to imitate them. Both left the bulk wine industry, sold their old wineries and developed new ones with frontier technology and equipment. Both succeded and are in a great deal responsible of the globalization of the Argentine insignia grapes: Malbec and Torrontés.

Their paths and approach to innovation were different, and in trying to stylize the processes we characterized Catena as an experimental innovator and Etchart together with Rolland as conceptual ones. In the Catena`s intent of producing locally wines of world class, he produced good Cabernets and Chardonnays but had unexpected results with Malbec and added to conventional knowledge the importance of height and soil. He achieved prizes and recognitiions of experts and markets, local followers who adopted his innovations, and prestigious international partners in ventures.

Etchart and Rolland collaboration also achieved the production and export of local wines of world class, and as an unexpected result Torrontés was increasingly accepted in the US market. They could produce good Malbec in a relatively peripherical wine region of Argentina, and their wineries are situated between the highest in the world. They also were awarded by their products and gain the interest of prestigious international partners. Etchart sold it old winery to global players and both developed new ventures. Mr. Rolland started a career as an international consultant and he also developed his own wineries in several 
countries in the world, as well as in different places in Argentina, along a line of 2,000 kilometers.

How does the process of applying knowledge to the industry work? For conceptual innovators, it is mainly through a preconceived and well-defined idea, while for experimental ones it is mainly through a process of trial and error. It seems that innovators start by asking "why?"- and "why not?"-type questions. The "because"-type responses are not immediate, especially for experimental innovators. Moreover, they are probably counterintuitive or at least imply they are swimming against the current. The aim to produce world class wines in Argentina in the 1980s meant abandoning an entire methodology, challenging the law of gravity, so to speak.

How do people innovate? In different ways: conceptual innovators contemplate the big picture and have a well-defined plan from the very beginning, while experimental ones build patiently with details and small pieces. Once the seed has been planted, a process begins with the idea that high quality wines can be "manufactured" using the proper combination of input and knowledge, or an initial trial motivated by a one's own self-esteem.

What is inside the innovation black box? Experimental innovators work inductively, slowly accumulating knowledge from experience. Conceptual innovators work deductively, applying ideas. Association, sparks of understanding, epiphanies are also part of the process.

What makes an innovation important? Two factors: novelty and influence. A key element of the two cases presented in this paper is that both innovations were adopted by wine producers. That is a powerful reason to explore the work of these innovators.

Can the innovation process be stylized? Yes, in this paper we made an initial effort to try and do so. This, in turn, is important as a way to explain the phenomena, as well as to derive managerial and policy actions.

\section{References}

Artopoulos, Alejandro, Daniel Friel and Juan Carlos Hallak (2013). Export emergence of differentiated goods from developing countries: Export pioneers and business practices in Argentina. Journal of Development Economics, Volume 105, Pages 19-35.

Bodega Catena Zapata (2017). http://www.catenawines.com/. Accessed May 29, 2017. 
Bustos, R. Javier, Julio Peña Torres and Manuel Willington (2007). Propiedad Extranjera y Especialización Productiva en la Industria del Vino en Chile. Investigación 184. Universidad Alberto Hurtado.

Catena, Laura (2017). Oro en los Viñedos. Catapulta Editores.

Cuculiansky, Sabrina (2016). En el vino, los puntajes no tienen futuro. Interview to Michel Rolland, April 3rd, La Nación.

Davinson, Charles. "How Was Steve Jobs Unlike Mark Twain? A Conversation with Economist David Galenson," Economic Research, Federal Reserve Bank of Atlanta, September 10, 2015.

Defrancesco, Edi, Jimena Estrella Orrego and Alejandro Genneri (2012). Would "New World" wines benefit from protected geographical indications in international markets? The case of Argentinean Malbec. Wine Economics and Policy 1 (2012) 63-72.

Fresco, Mariano (2018). El plan de Laura Catena para crear un vino que añeje por 100 años. El Cronista, 29 de enero. https://www.cronista.com/clase/dixit/El-plan-de-Laura-Catenapara-crear-un-vino-que-aneje-por-100-anos-20180126-0001.html

Galenson, David W. (2007). Old Masters and Young Geniuses: The Two Life Cycles of Artistic Creativity. Princeton University Press.

Galenson, David W. and Clayne Pope (2013). Collaboration in Science and Art. Huffington Post. https://www.huffingtonpost.com/david-galenson/collaboration-in-science_b_1687024.html

Hernández, Daniel (2013). Boom Varietal is a Love Letter to Argentine Malbec ... but like any love letter, it doesn't really have all that much to say. http://birthmoviesdeath.com/2013/09/13/badass-sommelier-boom-varietal-is-a-loveletter-to-argentine-malbec.

https://anuvawines.com/tasting-argentina/the-best-wines-of-argentina-2012cafayate-torrontes-by-bodegas-etchart/

Ibarguren, Roberto A. (2013). Review: San Pedro de Yacochuya Torrontés 2012. Wine Savvy on November 25, 2013.

Lima, T., and Schroder, N. (2009). Nossiter Jonathan (Director): Mondovino, Screenplay by Nossiter Jonathan, Velocity/Thinkfilm, 2004, 135 minutes. Journal of Wine Economics, 4(1), 119-121. 
Lucas, Robert E. and Benjamin Moll (2014). Knowledge Growth and the Allocation of Time," Journal of Political Economy, University of Chicago Press, vol. 122(1), pages 1 - 51.

Mount, Ian (2013). The Vineyard at the End of the World: Maverick Winemakers and the Rebirth of Malbec. W. W. Norton \& Company.

Nogueira, Tânia (2013). O homem que inventou o vinho Malbec. Revista Veja.

Personal Interview with Nicolás Catena (2016). Julio Elías, February $2^{\text {nd }}$ in Buenos Aires.

Polany, Michael (1998). Personal Knowledge. Towards a Post-Chritical Phylosophy. Routledge.

Rose, Anthony (2009). Interview with Nicolás Catena, Decanter man of the year 2009. http://www.decanter.com/features/interview-with-Nicolás-catena-decanter-man-ofthe-year-2009-246775/\#qzmytVeOxtilLOhK.99.

Saieg, Laura (2011). Caso empresa: Bodegas Etchart. www.areadelvino.com 29/03/2011.

Saieg, Laura (2013), Hacedores de vinos en Salta. www.areadelvino.com. 